\title{
Intraarticular Migration of Broken Patella Cerclage and Figure-of-Eight Wire
}

\author{
Iwan Budiwan Anwar*, Seti Aji Hadinoto, Okkie Mharga Sentana \\ Department of Orthopaedic and Traumatology, Faculty of Medicine, Sebelas Maret University, Orthopaedic Hospital Prof. Dr. \\ R. Soeharso, Surakarta, Indonesia
}

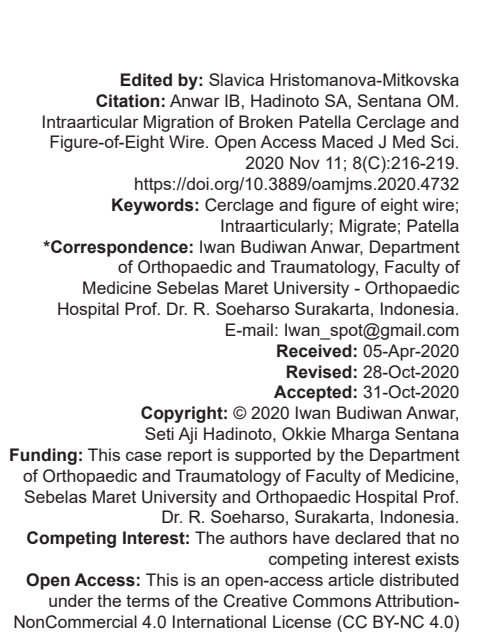

Abstract

BACKGROUND: Breakage of the wire commonly follows the procedure performed for displaced patellar fractures: nevertheless, there have not been many reports about wire fragment migration. To the best of our knowledge, there were only six documented cases of wire fragment intraarticular translocation.

CASE REPORT: A 47-year-old male patient, with a history of patella fracture 3 years ago, was treated with cerclage and figure-of-eight wiring, presented with severe restriction of knee movements for the past 4 weeks. X-ray and fluoroscopy examination showed cerclage wire had broken at multiple sites with one broken piece migrated posterior intraarticularly. This case is unique due to the size of the migrated broken cerclage wire, which was about only length $1.5 \mathrm{~cm}$ and diameter $1.25 \mathrm{~mm}$ attached to posterior lateral condyle which prevented its further migration; otherwise, it could damage neurovascular structures. This intraarticular piece of wire was removed successfully with fluoroscopy support.

CONCLUSION: Increased time-lapse from the initial surgery, the comminution of the fragment fracture, wire shape and size, and the incorrect placement of wire are the risk factors of intraarticular migration. We should educate the patient about the risks of hardware failure and possible migration with all patients receiving bone fixation with wires, and we can offer elective hardware removal as an option.

\section{Introduction}

There are various methods for the management of displaced patellar fractures, among them are tension band wiring, cerclage wiring, tension band wiring with cerclage wiring, and cerclage wiring with additional figure-of-eight wiring. Commonly, breakage of the wire follows the procedure, but there has not been any clear description about wire fragment migration [1], [2], [3]. To the best of our knowledge, there were only six documented cases of intraarticular translocation of wire fragment [3], [4], [5], [7], [8], [9].

\section{Case Report}

A 47-year-old male reported a complaint of left knee pain for a month. The patient had sustained a displaced comminuted fracture of his left patella and tibial plateau following a fall 3 years ago. Cerclage wire with an additional figure-of-eight wire fixation technique successfully performed, and the patient was recovering well. However, there was a lost to follow-up before the patella fracture had a union. The patient reported an excellent function of the left knee for the past 3 years and returned to his job without any pain or functional disability.

However, the patient started experiencing deep-seated pain within the right knee for the past 4 weeks. There was no recent history of any fall or trauma to the right knee. Clinical examination of the right knee revealed no patella or joint line tenderness. There was no effusion, and the cruciate and collateral ligaments were intact. Furthermore, there was no extensor lag and knee extension power was good. The range of motion of the knee was full at the point of clinical examination.

The previous radiograph of the left knee that taken 1 month before surgery has revealed a union of the patella fracture with the metal wires broken at several places (Figure 1). We saw that the inferolateral segment of the broken cerclage wire has migrated in front of the tibial tuberosity.

The patient underwent 2 times of surgery for removal of the patella wires because we only used an X-ray photograph 1 month ago, and we did not anticipate 


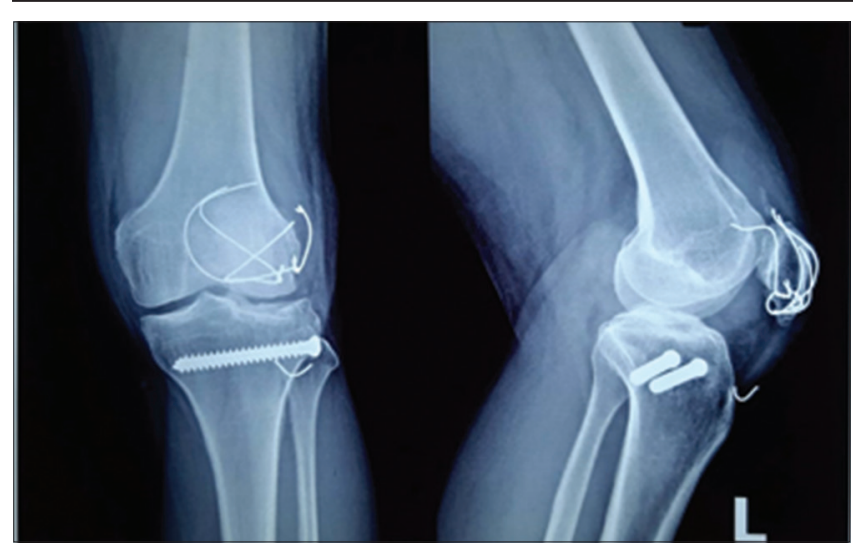

Figure 1: Previous radiograph at presentation demonstrated breakage and migration of $\mathrm{K}$-wire in front of tibial tuberosity

the possibility of this fragment migrating. After the first surgery, from post-operative radiograph, there was still a small fragment of the wire that migrated to the posterior part. Thus, we had to do the second stage operation to take that wire because it could damage the surrounding neurovascular structures. We used fluoroscopy guiding to identify the precise location of the broken wire (Figure 2).

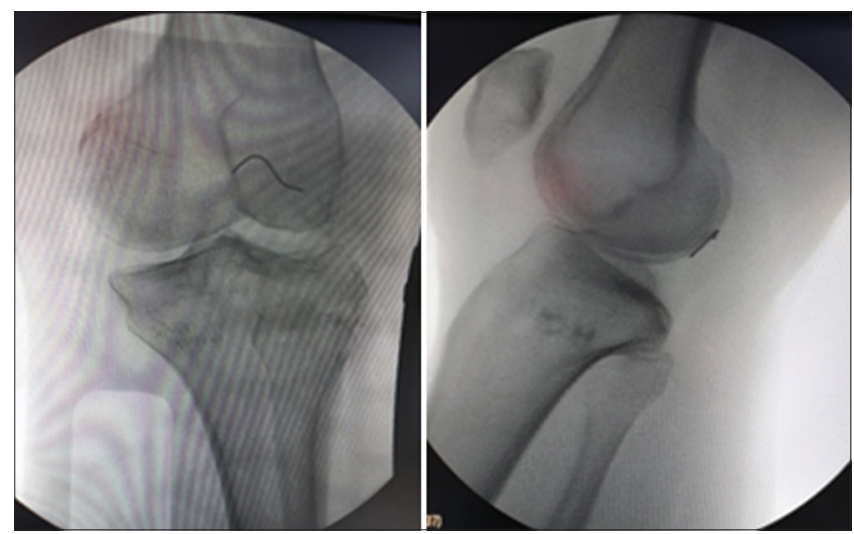

Figure 2: One small wire was left behind at the posterior lateral condyle (fluoroscopy)

We used a new posterior approach to remove this wire. After we identified the location under fluoroscopy, we must divide the hamstring muscles and make an incision of the posterior capsule to reach the wire (Figure 3a). At last, we found the migrated wire that was tiny with length $1.5 \mathrm{~cm}$ and diameter $1.25 \mathrm{~mm}$, slim, tubular, and unthreaded shape and was hooked intraarticularly at the base of the posterior lateral condyle (Figure $3 b$ ).

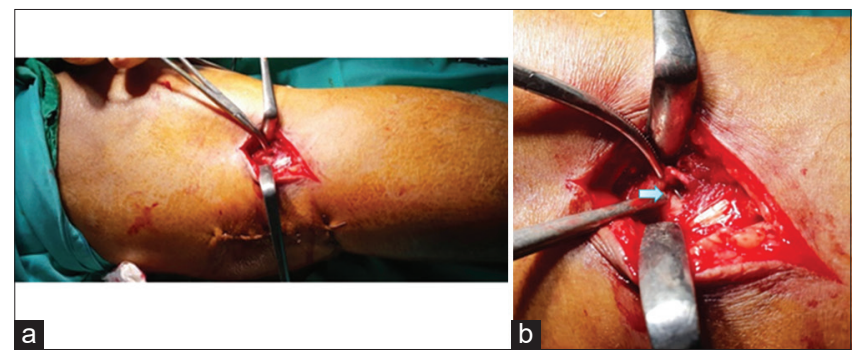

Figure 3: (a) Posterior approach of the left knee. (b) The wire was found attached intraarticularly to posterior lateral condyle

The patient was discharged 1 day following surgery, and his wound healed in 2 weeks. Symptoms of knee pain and locking knee resolved completely following the surgery, and the patient was able to resume work in 2 weeks.

\section{Discussion}

From the previous study, there were very few studies that reported cases of wire fragment translocation after patellar fracture fixation. Whereas, the broken wires in the patellar fracture can migrate intraarticularly [3], [9] to the popliteal fossa ${ }^{1}$ and even to the heart [2]. Biddau et al. reported a rare case of migration of patella cerclage wire into the heart. The fragment might pass through the blood circulation [2]. Two cases of extraarticular patella wire migration to the popliteal fossa were reported by Choi et al. [1]. It is important to remember that the posterior section of the knee is close to the neurovascular bundle, so nerve irritation can occur when the broken wire fragment migrates to this area [1]. In particular, we found only six cases of intraarticular migration of a patella wire in the literature [3], [4], [5], [8], [9] (Table 1). Unfortunately, we only found a little information on one case from Chen et al.

The migration of $\mathrm{K}$-wires is well established. K-wires have a strong tendency to pass through the path of their insertion as a result of their slim, tubular, and unthreaded shape. The free fragments from the breakage of the wire then easily travel through the smallest resistance pathway [6].

According to Wang et al. [4], without a fracture gap, it is unlikely that the wire can travel intraarticularly because the wire fragment needs to penetrate a substantial amount of soft tissues, such as the thick retinaculum, before entering the knee joint. However, it is not impossible. In most cases, the nonunion site is repopulated by fibrous scar tissue that aligns intimately with the pseudarthrosis line, building a forceful barrier. However, a dynamic gap without fibrous tissue has opened up an unexpected portal for the broken wire's entry into the knee joint [4].

An exciting finding showed a case of intraarticular migration without nonunion and Chen et al. [3] hypothesized that the too-posteriorplacement of the cerclage wire around the patella could be the root cause. That area contained no or very little soft soft-tissue buttress. Hence, when the wire broke, its fragment could pierce through the joint capsule easily [3]. In our case, the broken wire might migrate through the knee joint because the placement of the cerclage wire around the patella was too posterior.

Sammy [10] suggested that the difference between the patient's age in the entire wire group and the broken wire group was not statistically significant. However, there was a statistically significant difference 
Table 1: Six cases of intraarticular migration of a patella wire

\begin{tabular}{|c|c|c|c|c|c|c|c|c|c|c|c|}
\hline S. No. & Authors & Demographic & $\begin{array}{l}\text { Type of } \\
\text { fracture }\end{array}$ & Type of fixation & $\begin{array}{l}\text { Time duration } \\
\text { after surgery }\end{array}$ & $\begin{array}{l}\text { Symptoms } \\
\text { and duration }\end{array}$ & $\begin{array}{l}\text { Size of } \\
\text { the wire }\end{array}$ & $\begin{array}{l}\text { Location of } \\
\text { the broken } \\
\text { wire }\end{array}$ & $\begin{array}{l}\text { Possible risk } \\
\text { factor for } \\
\text { intraarticular } \\
\text { migration }\end{array}$ & $\begin{array}{l}\text { Surgical } \\
\text { treatment }\end{array}$ & Approach used \\
\hline 1 & $\begin{array}{l}\text { Chen } \\
\text { et al. }\end{array}$ & Unknown & Unknown & $\begin{array}{l}\text { Circumferential } \\
\text { wiring }\end{array}$ & Unknown & Unknown & Unknown & Unknown & $\begin{array}{l}\text { Improper } \\
\text { surgical } \\
\text { technique and } \\
\text { incorrect choice } \\
\text { of fixation }\end{array}$ & Unknown & Unknown \\
\hline 2 & $\begin{array}{l}\text { Sharma } \\
\text { et al. }\end{array}$ & $\begin{array}{l}51 \text {-year-old } \\
\text { male, Indian } \\
\text { origin }\end{array}$ & $\begin{array}{l}\text { Comminuted } \\
\text { fracture of } \\
\text { patella }\end{array}$ & $\begin{array}{l}\text { Modified } \\
\text { tension band } \\
\text { wiring with } \\
\text { cerclage and } \\
\text { figure-of-eight } \\
\text { wiring }\end{array}$ & $\begin{array}{l}15 \text { months } \\
\text { ago }\end{array}$ & $\begin{array}{l}\text { Deep-seated } \\
\text { pain within } \\
\text { knee with } \\
\text { restriction of } \\
\text { movements } \\
\text { for the last } \\
4 \text { weeks }\end{array}$ & $\begin{array}{l}\text { Length: } \\
4.5 \mathrm{~cm} \text {, } \\
\text { diameter: } \\
\text { unknown }\end{array}$ & $\begin{array}{l}\text { At the base } \\
\text { of anterior } \\
\text { cruciate } \\
\text { ligament until } \\
\text { posterior } \\
\text { compartment } \\
\text { of knee }\end{array}$ & $\begin{array}{l}\text { Activity level } \\
\text { and age, } \\
\text { improper } \\
\text { surgical } \\
\text { technique, and } \\
\text { incorrect choice } \\
\text { of fixation }\end{array}$ & $\begin{array}{l}\text { Arthroscopic } \\
\text { examination, } \\
\text { removal } \\
\text { of implant } \\
\text { by open } \\
\text { incision under } \\
\text { fluoroscopy }\end{array}$ & $\begin{array}{l}\text { Anteromedial } \\
\text { and anterolateral } \\
\text { portal for } \\
\text { arthroscopic } \\
\text { examination and } \\
\text { midline anterior } \\
\text { knee incision } \\
\text { for removal of } \\
\text { implant }\end{array}$ \\
\hline 3 & $\begin{array}{l}\text { Wang } \\
\text { et al. }\end{array}$ & $\begin{array}{l}\text { 61-year- } \\
\text { old male, } \\
\text { Chinese } \\
\text { origin }\end{array}$ & $\begin{array}{l}\text { Comminuted } \\
\text { fracture }\end{array}$ & $\begin{array}{l}\text { Modified } \\
\text { tension band } \\
\text { wiring with } \\
\text { figure-of-eight } \\
\text { wiring }\end{array}$ & 8 years ago & $\begin{array}{l}\text { Deep-seated } \\
\text { pain and } \\
\text { intermittent } \\
\text { locking within } \\
\text { the knee for } \\
\text { the last } \\
2 \text { weeks }\end{array}$ & Unknown & $\begin{array}{l}\text { Medial and } \\
\text { posterolateral } \\
\text { compartment } \\
\text { of the knee } \\
\text { joint }\end{array}$ & $\begin{array}{l}\text { Activity level and } \\
\text { age, nonunion } \\
\text { gap, improper } \\
\text { surgical } \\
\text { technique, and } \\
\text { incorrect choice } \\
\text { of fixation }\end{array}$ & $\begin{array}{l}\text { Arthroscopic } \\
\text { examination, } \\
\text { removal of } \\
\text { implant by } \\
\text { open incision }\end{array}$ & $\begin{array}{l}\text { Midline } \\
\text { anterior and } \\
\text { posterolateral } \\
\text { knee incision }\end{array}$ \\
\hline 4 & $\begin{array}{l}\text { Hsu } \\
\text { et al. }\end{array}$ & $\begin{array}{l}\text { 32-year-old, } \\
\text { male }\end{array}$ & Unknown & Cerclage wiring & 14 years ago & $\begin{array}{l}\text { Progression } \\
\text { medial side } \\
\text { knee pain } \\
\text { (exacerbated } \\
\text { by applying a } \\
\text { varus force) } \\
\text { and swelling } \\
\text { for unknown } \\
\text { duration }\end{array}$ & Unknown & $\begin{array}{l}\text { Intraarticular } \\
\text { medial } \\
\text { compartment } \\
\text { of the knee } \\
\text { joint and } \\
\text { extraarticular } \\
\text { posterolateral } \\
\text { of proximal } \\
\text { tibia }\end{array}$ & Unknown & $\begin{array}{l}\text { Removal of } \\
\text { implant by } \\
\text { arthroscopic }\end{array}$ & $\begin{array}{l}\text { Anteromedial } \\
\text { portal }\end{array}$ \\
\hline 5 & $\begin{array}{l}\text { Hsu } \\
\text { et al. }\end{array}$ & $\begin{array}{l}\text { 42-year-old, } \\
\text { female }\end{array}$ & Unknown & Cerclage wiring & 3 months ago & $\begin{array}{l}\text { A sudden } \\
\text { onset of left } \\
\text { knee swelling } \\
\text { and stiffness } \\
\text { for } 3 \text { months }\end{array}$ & Unknown & $\begin{array}{l}\text { Intraarticular } \\
\text { retropatellar } \\
\text { space }\end{array}$ & Unknown & $\begin{array}{l}\text { Removal of } \\
\text { implant by } \\
\text { arthroscopic }\end{array}$ & $\begin{array}{l}\text { Anteromedial } \\
\text { portal }\end{array}$ \\
\hline 6 & $\begin{array}{l}\text { Tamaki } \\
\text { et al. }\end{array}$ & $\begin{array}{l}75 \text {-year-old } \\
\text { man }\end{array}$ & $\begin{array}{l}\text { Transverse } \\
\text { fracture }\end{array}$ & $\begin{array}{l}\text { Tension band } \\
\text { wiring with } \\
\text { figure-of-eight } \\
\text { and cerclage } \\
\text { wiring }\end{array}$ & 2 years ago & $\begin{array}{l}\text { The wire had } \\
\text { perforated } \\
\text { the skin } \\
\text { anteriorly }\end{array}$ & Unknown & $\begin{array}{l}\text { Intraarticular } \\
\text { into the } \\
\text { posterior } \\
\text { septum of } \\
\text { knee joint }\end{array}$ & $\begin{array}{l}\text { Activity level } \\
\text { and age, lost } \\
\text { to follow-up, } \\
\text { improper } \\
\text { surgical } \\
\text { technique }\end{array}$ & $\begin{array}{l}\text { Removal of } \\
\text { implant by } \\
\text { arthroscopic }\end{array}$ & $\begin{array}{l}\text { Anteromedial } \\
\text { and } \\
\text { posteromedial } \\
\text { portal }\end{array}$ \\
\hline
\end{tabular}

for the duration from fracture fixation to implant removal between the two groups. The risk of wire breakage might increase with time after patellar tension band wiring. Elevated risk of wire breakage was found in a group of patients with removal procedure at more than or equal to 12 months from their initial fixation. The longer duration was related to a further increase in the relative risk. The tension-band and cerclage wires inside the quadriceps and patellar tendons are subjected to repetitive loading and strain even after the fracture has fused. Therefore, the risk for wires' breakage will likely to increase if not removed as time goes by. However, this risk is not related to the patients' age upon fracture fixation [10].

The risks factor of intraarticular migration broken wire, in this case, is the duration of the implanted wire since the initial surgery, the comminution of the fragment fracture, wire shape and size, and the placement of wire from previous surgery. In this case, the duration of the implanted wire since the initial surgery was 3 years. The comminution of the fragment fracture possible to made nonunion site, dynamic gap, and opened up an unexpected portal for the broken wire's entry into the knee joint. The placement of wire from previous surgery was too posterior from the patella itself and was not following the technique recommended by $\mathrm{AO}$. The following area contained no or very little soft soft-tissue buttress. When the wire broke, its fragment could pierce through the joint capsule easily. The migrated fragment of wire was tiny with length $1.5 \mathrm{~cm}$ and diameter $1.25 \mathrm{~mm}$ $(1.5 \mathrm{~cm})$, and the piece was hooked intraarticularly at the base of the posterior lateral condyle to prevent further migration. Otherwise, it could cause damage to surrounding neurovascular structures. In our patient, chronic knee pain for 3 months prompted the patient to seek medical attention. The intraarticular wire was mobile in the joint and produced pain knee symptoms intermittently.

The patient had to undergo operation 2 times because we only used X-ray photograph 1 month ago, and we did not anticipate the possibility of this fragment migrating. For the second stage operation, we had to make a new posterior incision and split the hamstring muscle and cut the posterior capsule to identify this piece.

Several recent techniques have developed to reduce the risk of complications related to conventional tension band wiring using K-wires and metal wires. Berg suggested the technique of tension band wiring through cannulated screws instead of K-wires [11]. Qi et al. improved this technique using bioabsorbable 
cannulated screws with a braided polyester suture [12]. Braided polyblend sutures and metallic ring pins were used by Yotsumoto et al. to treat transverse patellar fractures [13]. They claimed that the ring pins and braided polyblend suture would not travel from the reduction site so that it can decrease the complications related to metallic materials. However, until now, the conventional tension band wiring proposed by the $A O$ Foundation is still the most considerably used despite a lower complication rate using the novel techniques mentioned.

Patients with wire breakage frequently refuse the removal surgery, moreover, when they do not feel any symptom. Unfortunately, our case was lost to follow-up because it was asymptomatic. The patient usually asked for wire removal surgery only when there was a complaint of pain over his knee.

From this case, we can learn about the risk factors of intraarticular migration broken wire of patella, the importance of the latest radiograph before removal of implant to anticipate the possibility of the migrating fragment, doing a careful fixation with cerclage or tension band wiring proposed by the AO Foundation and long-term gradual follow-up. We should explain to the patients the possibility of critical complications because they can migrate to the neurovascular bundles in the popliteal fossa ${ }^{1}$ and the heart through the venous system [2]. Once the wire breakage happened, the patient should be strongly advised to have the removal procedure. We must anticipate the harmful effects of intraarticular migration of wires. Joint tenderness, locking symptoms, higher risks of infection, and early degenerative joint disease are the complications, we need to pay attention to [4].

\section{Conclusion}

Increased time-lapse from the initial surgery, the comminution of the fragment fracture, wire shape and size, and the incorrect placement of wire from previous surgery are the risk factors of intraarticular migration. We should discuss and educate the patient about the risks of hardware failure and possible migration with all patients receiving bone fixation with wires, and we can offer elective hardware removal as an option. Furthermore, when radiological examination observes any wire breakage, particularly in the presence of nonunion, the patient should be verily counseled to undergo wire removal procedure as soon as possible.

\section{References}

1. Choi HR, Min KD, Choi SW, Lee BI. Migration to the popliteal fossa of broken wires from a fixed patellar fracture. Knee 2008;15(6):491-3. https://doi.org/10.1016/j.knee.2008.06.005 PMid:18752955

2. Biddau F, Fioriti M, Benelli G. Migration of a broken cerclage wire from the patella into the heart. A case report. J Bone Joint Surg Am 2006;88(9):2057-9. https://doi.org/10.2106/jbjs.e.00968 PMid:16951124

3. Chen YJ, Wu CC, Hsu RW, Shih $\mathrm{CH}$. The intra-articular migration of the broken wire: A rare complication of circumferential wiring in patellar fractures. Changgung Yi Xue Za Zhi 1994;17(3):276-9. PMid:7954008

4. Wang L, Lee KT. Locking knee after intra-articular migration of broken patella tension band wire: An extraordinary intra-articular migration via pseudarthrosis line. Acta Orthop Traumatol Turc 2013;47(6):444-7. https://doi.org/10.3944/aott.2013.2990 PMid:24509227

5. Tamaki Y, Nakayama T, Kita K, Miyatake K, Kawasaki Y, Fujji K, et al. Arthroscopic removal of a wire fragment from the posterior septum of the knee following tension band wiring of a patella fracture. Case Rep Orthop 2015;2015:827140. https://doi. org/10.1155/2015/827140

PMid:25737791

6. Meena S, Nag HL, Kumar S, Barwar N, Mittal S, Singla A. Delayed migration of K-wire into popliteal fossa used for tension band wiring of patellar fracture. Chin Med Assoc 2013;16(3):186-8. PMid:23735556

7. Konda SR, Dayan A, Egol KA. Progressive migration of broken Kirschner wire into the proximal tibia following tension band wiring technique of a patellar fracture--case report. Bull NYU Hosp Jt Dis 2012;70(4):279-82.

PMid:23267457

8. Kumar S, Sharma SK, Aslam M, Chadha GN. Intra-articular migration of broken patellar tension band wire: A rare case. $\mathrm{J}$ Orthop Case Rep 2016;6(5):41-3.

PMid:28507964

9. Hsu WH, Huang HC, Tsai YH, Peng KT, Hsu R. Fluoroscopiccontrolled, arthroscopic removal of intra-articular broken wire after patellar fracture. Injury Extra 2006;37:86-9. https://doi. org/10.1016/j.injury.2005.08.016

10. Sammy MN. Breakage and migration of metal wires in operated patella fractures: Does it correlate with time? J Orthop Trauma Rehabil 2013;17:13-6. https://doi.org/10.1016/j.jotr.2012.04.003

11. Berg EE. Open reduction internal fixation of displaced transverse patella fractures with figure-eight wiring through parallel cannulated compression screws. J Orthop Trauma 1997;11:57376. https://doi.org/10.1097/00005131-199711000-00005

12. Qi L, Chang C, Xin T, Xing PF, Tianfu Y, Gang Z, et al. Double fixation of displaced patella fractures using bioabsorbable cannulated lag screws and braided polyester suture tension bands. Injury 2011;42:1116-20. https://doi.org/10.1016/j.injury.2011.01.025 PMid:21345433

13. Yotsumoto T, Nishikawa U, Ryoke K, Nozaki K, Uchio Y. Tension band fixation for treatment of patellar fracture: Novel technique using a braided polyblend sutures and ring pins. Injury 2009;40:713-7. https://doi.org/10.1016/j.injury.2008.10.032 PMid:19233355 